\title{
ClpB Is the Escherichia coli Heat Shock Protein F84.1
}

\author{
CATHERINE L. SQUIRES, ${ }^{1 *}$ STEEN PEDERSEN, ${ }^{2}$ BARBARA M. ROSS,${ }^{1}$ AND CRAIG SQUIRES ${ }^{1}$ \\ Department of Biological Sciences, Columbia University, New York, New York 10027, ${ }^{1}$ and University Institute of \\ Microbiology, University of Copenhagen, DK-1353 Copenhagen K, Denmark ${ }^{2}$
}

Received 12 April 1991/Accepted 8 May 1991

\begin{abstract}
ClpB is thought to be involved in proteolysis because of its sequence similarity to the ClpA subunit of the ClpA-ClpP protease. It has recently been shown that ClpP is a heat shock protein. Here we show that ClpB is the Escherichia coli heat shock protein F84.1. The F84.1 protein was overproduced in strains containing the $c l p B$ gene on a plasmid and was absent from two-dimensional gels from a $c l p B$ null mutation. Besides possessing a slower growth rate at $44^{\circ} \mathrm{C}$, the null mutant strain had a higher rate of death at $50^{\circ} \mathrm{C}$. We used reverse transcription of in vivo $\mathrm{mRNA}$ to show that the $c l p B$ gene was expressed from a $\sigma^{32}$-specific promoter consensus sequence at both 37 and $42^{\circ} \mathrm{C}$. We noted that the $c l p B^{+}$gene also caused the appearance of a second protein spot, F68.5, on two-dimensional gels. This spot was approximately 147 amino acids smaller than F84.1 and most probably is the result of a second translational start on the clpB mRNA. F68.5 can be observed on many published two-dimensional gels of heat-induced $E$. coli proteins, but the original catalog of 17 heat shock proteins did not include this spot.
\end{abstract}

clpB is the gene immediately preceding the Escherichia coli rRNA $G$ operon $(r r n G)$ and was first noted in studies on $r r n G$ regulation $(1,32)$. Proteins homologous to $\mathrm{ClpB}$ were subsequently found in diverse organisms. $E$. coli also possesses a second $\mathrm{ClpB}$ homolog, ClpA (11), which has been implicated in ATP-dependent proteolysis $(13,14)$. These homologs will therefore be called the Clp protein family in this paper. Other examples of this highly conserved family have been identified both in the true bacteria Bacteroides nodosus (11), Mycobacterium leprae, (21), Rhodopseudomonas blastica (36), and Streptococcus mutans (33) and in the eukaryotes Lycopersicon esculentum (11), Saccharomyces cerevisiae (18), and Trypanosoma brucei (11). Hybridization of an $E$. coli $\operatorname{clpB}$ probe to DNA isolated from different organisms extends this list to Drosophila melanogaster, Caenorhabditis elegans, and the archaebacterium Methanosarcana acetivorans (11). These examples from all three kingdoms suggest that the Clp family is universal. Although the sizes of different Clp proteins vary considerably (756 to 926 amino acids), all possess two very highly conserved regions comprising 234 and 192 amino acids that share at least $80 \%$ similar and $50 \%$ identical amino acids between the most distantly related examples. Both highly conserved regions contain nucleoside triphosphate-binding consensus sequences $(6,40)$. These regions are enclosed between somewhat more variable leader and trailer sequences and separated by a highly variable spacer sequence (11) (Fig. 1).

This paper presents evidence that $\mathrm{ClpB}$ is a heat shock protein. The proteolytic component of the ClpA-ClpP protease, ClpP, has also recently been identified as the heat shock protein F21.5 (16). Upon a shift from low to high temperature, $E$. coli responds by a transient synthesis of about 20 specific proteins. Many proteins involved in this response are under the control of the $r p o H$ gene $(12,22)$, specifying the unique heat shock $\sigma^{32}$ factor, which directs transcription from a special $\sigma^{32}$-specific promoter consensus sequence (22). This response of cells to the heat shock stress is universal (17) and is characterized by a high degree of

\footnotetext{
* Corresponding author.
}

sequence conservation and functional unity of the proteins involved (31). Many of these proteins act as molecular chaperones, devoted to stabilization and transport of certain proteins (Hsp90, Hsp60, and GroEL) and to the renaturation (Hsp70 and DnaK) or breakdown (the ubiquitin system and Lon) of proteins denatured during the period of heat stress. The $E$. coli heat shock proteins have been named by standard alphanumeric designations of spots separated on twodimensional gels $(23,25)$. At least 17 heat shock proteins have been catalogued by this method (22).

In this paper we have compared by two-dimensional gel electrophoresis the protein patterns of strains carrying wildtype $\operatorname{clp} B$, a $\operatorname{clp} B$ null mutation, and a plasmid carrying $c l p B$. We have shown that the $\operatorname{clp} B$ gene specifies two heat shock proteins, F84.1 and the previously unnoted F68.5. The properties of $\mathrm{ClpB}$ calculated from the nucleotide sequence are in rough agreement with the size and isoelectric point obtained experimentally for F84.1. Although the exact relationship of F68.5 to the $c l p B$ sequence remains unknown, our current hypothesis is that F68.5 originates from $c l p B$ mRNA by internal translational reinitiation. Growth and viability experiments with $\operatorname{clp} B$ null and wild-type strains have shown that the $\operatorname{clpB}$ null mutation caused a slower growth rate at $44^{\circ} \mathrm{C}$ and reduced cell survival at $50^{\circ} \mathrm{C}$ significantly. We have concluded that the $\operatorname{clpB}$ gene is necessary for survival at high temperature.

\section{MATERIALS AND METHODS}

Strains and plasmids. We list the $E$. coli strains and the plasmids used in this work in Table 1.

Chemicals and enzymes. ${ }^{35} \mathrm{~S}$-methionine $(1,000 \mathrm{Ci} / \mathrm{mmol})$ was purchased from New England Nuclear, Boston, Mass. ${ }^{32} \mathrm{P}$-dATP, $800 \mathrm{Ci} / \mathrm{mmol}$, was purchased from Amersham, Inc., Chicago, Ill. Avian myeloblastosis virus reverse transcriptase was purchased from GIBCO BRL, Gaithersburg, Md.

Nucleotide and amino acid sequences. We have previously entered the nucleotide sequence of the $\operatorname{clp} B$ gene into GenBank (accession number M28364). This sequence contains the entire 2,580-nucleotide $\operatorname{clp} B$ coding sequence plus 546 preceding and 1,121 following nucleotides. We have 


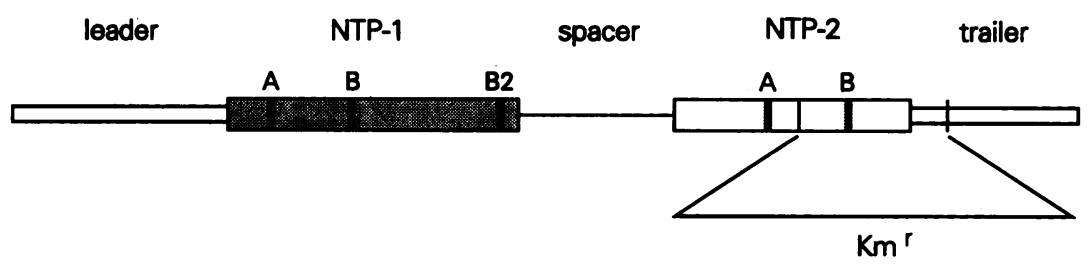

FIG. 1. Schematic of ClpB protein showing regions of varying conservation. Thicker boxes are more highly conserved in Clp examples derived from eukaryotes and from the $E$. coli $\mathrm{ClpA}$ and other prokaryotes. Parts of the protein are identified as leader, spacer, and trailer, delimiting two highly conserved regions, NTP-1 and NTP-2. These highly conserved regions possess the nucleotide-binding consensus sequences segment $A\left(K / R-X_{4}-G-X_{4}-G K T\right)$ and segment $B\left(R / K-X_{5-8}-\Phi_{4}-D\right)(X$, any amino acid; $\Phi$, aromatic amino acids) $(6,11,40)$. In addition, NTP-1 has a second B segment, designated B2, whose function is unknown. The position of the kanamycin resistance cassette (Km $\left.{ }^{r}\right)$

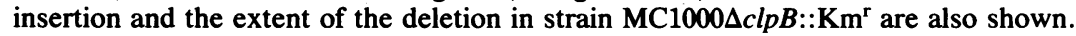

used the nucleotide numbering scheme of the GenBank entry throughout this paper for specifying the locations of features. The sequence was derived from two complementary single-stranded M13 clones, BP1 and PB1, and the plasmid clone, pKB3-5 (see below). We made the phage by cloning a 3.5-kbp BamHI-PstI fragment from pLC23-30 into M13mp8 and M13mp19 vector DNAs cleaved with BamHI and PstI, thereby providing complementary clones of the proximal $88 \%$ of the $c l p B$ gene. The last 300 nucleotides of $c l p B$ were published previously with the $r r n G$ control region sequence (32). We employed synthetic DNA primers and DNA chain termination to sequence the $\operatorname{clpB}$ gene, using M13 (singlestranded) and pKB3-5 (double-stranded) templates (42). Sequence information was obtained from both strands for the entire region, except for nucleotides 1 to 60 , that were sequenced only as antisense information. We have also published the ClpB amino acid sequence previously (11).

Construction of pClpB. We constructed two different plasmids containing the $c l p B$ gene. The first, pKB3-5, was made by inserting a 6.1-kbp SmaI fragment from the ClarkeCarbon collection clone pLC23-30 into the plasmid pKK232-8. This SmaI fragment contains the entire $c l p B$ gene, plus the following rrnG P1P2 control region and 612 nucleotides of mature 16S rRNA sequence. Approximately
1,500 bp of chromosomal sequences upstream of $c l p B$ are also contained on pKB3-5.

In the second construction, $\mathrm{pClpB}$ was made by removing the $r r n G$ sequences from $\mathrm{pKB} 3-5$. No convenient restriction sites permitted separation of the $c l p B$ gene from $r r n G$ sequences, so we used the polymerase chain reaction to separate these genes. $\mathrm{pClpB}$ was constructed in four steps. The construction was designed to end the sequence immediately following the $\operatorname{clp} B$ transcription terminator by substituting the distal $13 \%$ of the $c l p B$ gene with a synthetic polymerase chain reaction copy (Fig. 2). First, we used the synthetic DNA primers OBG14 (CCGACTGCCTCCCTGT GCTG; nucleotides 10 to 29) and OBG0 (CGCTCACTTTTC AGGCA; nucleotides 3219 to 3203) with MC1000 template DNA to make a 3,210-bp fragment containing the entire $c l p B$ gene, including its transcription termination region. We cleaved this fragment with HindII and ligated the resulting 542-bp terminator-containing fragment into M13mp19 DNA cleaved with HindII. Recombinant phage were screened by sequencing, and one, mp19-clpBt4, was saved. Second, we purified the $c l p B$ internal 479-bp BamHI-EcoRI fragment from pKB3-5 and the 420-bp EcoRI-BamHI fragment from mp19-clpBt4 (the BamHI site of this fragment is from the mp19 multicloning site). These fragments were ligated and

TABLE 1. Strains, plasmids, and phage used in this study

\begin{tabular}{|c|c|c|}
\hline Designation & Genotype or description & Source or reference \\
\hline \multicolumn{3}{|l|}{ Strains } \\
\hline CSR603 & recAl uvrA6 phr & 29 \\
\hline JC7623 & arg ara his leu pro recB21 recC22 sbcB15 thr & M. Winkler (2) \\
\hline MC1000 & $\Delta($ lacIPOZY $)$ galU galK $\Delta$ (ara-leu) rpsL spoT relA & M. Casadaban (5) \\
\hline MC1009 & $\Delta($ lacIPOZY $)$ galU galK $\Delta$ (ara-leu) rpsL srl::Tn10 recA56 spoT relA & M. Casadaban \\
\hline $\mathrm{MC} 1000 \Delta c l p B:: \mathrm{Km}^{\mathrm{r}}$ & MC1000 $\Delta$ clpB $:: \mathrm{Km}^{\mathrm{r}}$ & M1000 and pMB2190; this paper \\
\hline \multicolumn{3}{|l|}{ Plasmids } \\
\hline pKK232-8 & cat promoter vector & J. Brosius (4) \\
\hline pLC23-30 & clpB $r r n G$ & L. Clarke and M. Nomura (7) \\
\hline pKB3-5 & $\operatorname{clpB} \operatorname{rrn} G^{\prime a}$ & pLC23-30 and pKK232-8 (3) \\
\hline pClpB & pKB3-5 minus $r r n G$ sequences & pKB3-5 and M13clpBt4; this paper \\
\hline pMB2190 & $\mathrm{Km}^{\mathrm{r}} \mathrm{Ap}^{\mathrm{r}}$ in $\mathrm{pBR} 327$ & M. Winkler (2) \\
\hline \multicolumn{3}{|l|}{ Phage } \\
\hline M13mp8 & Cloning vector & J. Messing \\
\hline M13mp19 & Cloning vector & J. Messing \\
\hline M13BP1 & $\operatorname{clpB}(+)^{b} ;$ BamHI-PstI & pLC23-30 and M13mp8; this paper \\
\hline M13PB1 & $\operatorname{clpB}^{\prime}(-) ;$ PstI-BamHI & pLC23-30 and M13mp19; this paper \\
\hline M13clpBt4 & 'clpB(+); HincII-BamHI & $\mathrm{PCR}^{c}$ of $\mathrm{MC} 1000$ and $\mathrm{M} 13 \mathrm{mp} 19$; this paper \\
\hline
\end{tabular}

${ }^{a}$ The prime symbol signifies that the cloned gene is incomplete on the side indicated.

$b(+)$ signifies that the M13 clone hybridizes to $\operatorname{clpB}$ mRNA, while (-) signifies the opposite M13 clone.

c PCR, polymerase chain reaction. 


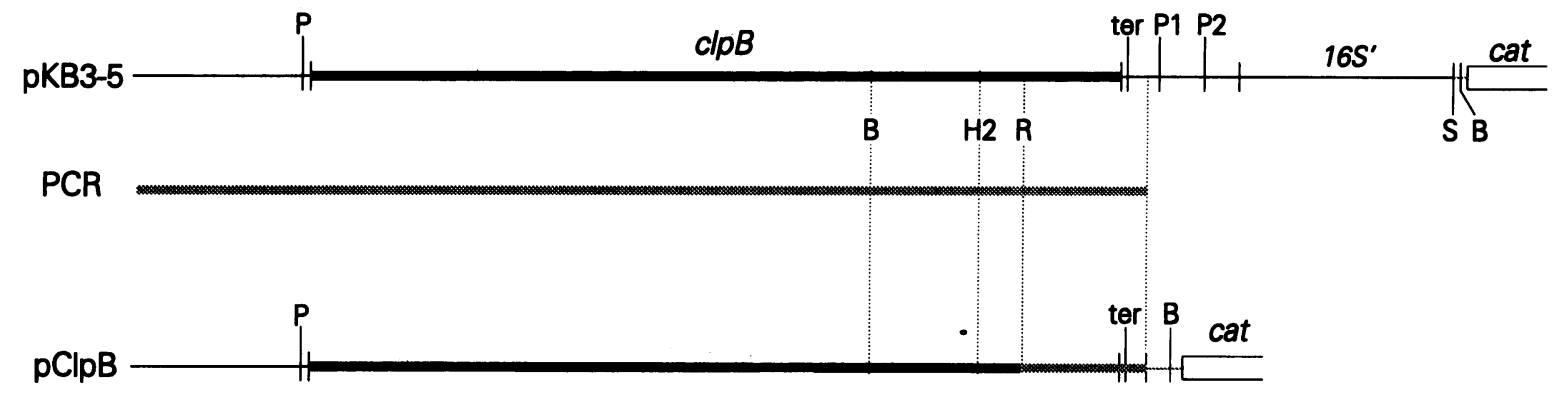

FIG. 2. Relationship of pClpB to pKB3-5. The relevant portions of plasmids pKB3-5 and pClpB are shown, as well as the extent of the polymerase chain reaction (PCR)-synthesized DNA derived from an MC1000 chromosomal clpB template. pKB3-5 contains the entire clpB gene and segments of the $r r n G$ operon fused to the reporter gene, the chloramphenicol acetyltransferase gene (cat). Thick solid lines indicate $c l p B$ gene sequences from pKB3-5. Thick shaded lines indicate the DNA portion synthesized by PCR. Thin solid lines indicate chromosomal DNA sequences. The thin dotted lines indicate synthetic sequences derived from the M13 vector, mp19, or from pKK232-8. P, clpB gene promoter; ter, transcriptional terminator for the $c l p B$ gene; $\mathrm{P} 1$ and $\mathrm{P} 2, r r n G$ operon promoters; $16 S^{\prime}$, initial part of the $r r n G 16 \mathrm{~S}$ gene; $\mathrm{B}$, BamHI; R, EcoRI; H2, HindII; S, SmaI.

then cleaved with BamHI to create an 898-bp BamHI fragment containing the end of the $\operatorname{clp} B$ gene. Third, we removed the 1,861-bp $B a m H I$ fragment that extends from the site in $c l p B$ to the multicloning site of pKB3-5. This fragment contained all of the $r r n G$ sequences that are on pKB3-5. Fourth, the 898-bp BamHI fragment from step two was ligated into the BamHI-cleaved vector fragment prepared in step three. This step regenerated the intact clpB gene. We checked this plasmid by both restriction mapping and sequencing and called it pClpB.

Insertion of $\mathbf{a ~ K m}^{\mathbf{r}}$ cassette into the $\operatorname{clp} B$ gene. To inactivate $c l p B$, we cleaved pKB3-5 DNA with ClaI. This removed 375 bp from within the $\operatorname{clpB}$ gene (nucleotides 2451 to 2826). (A third ClaI site in $c l p B$ [position 1737] is modified by methylation and therefore not cleaved by this restriction enzyme.) A 1,250-bp $\mathrm{Km}^{\mathrm{r}}$-containing fragment was obtained by $A c c \mathrm{I}$ digestion of pMB2109 DNA (2). This generated sticky ends that were compatible with the ends obtained from the pKB3-5 ClaI digestion. After isolation, we verified the deletion-insertion plasmid by restriction mapping and sequence analysis. We then used fragment transformation of a recBC $s b c B$ strain, JC7623 (2), to replace the chromosomal copy of $\operatorname{clp} B$ with the inactivated plasmid copy. Using P1 transduction, we then transferred the inactivated gene, $\Delta c l p B:: \mathrm{Km}^{\mathrm{r}}$, into strain $\mathrm{MC1000}$ for all subsequent studies (20). Southern analyses of chromosomal DNA preparations from $\Delta c l p B:: \mathrm{Km}^{\mathrm{r}} \mathrm{MC1000}$ transductants confirmed the presence of the $c l p B$ deletion-insertion in the MC1000 genome (data not shown). This deletion-insertion is at the carboxylterminal end of the gene. In the $\mathrm{ClpB}$ protein, this corresponds to the distal half of the second nucleoside triphosphate-binding consensus and the beginning of the trailer region (Fig. 1).

Two-dimensional protein gel electrophoresis. Protein labeling with ${ }^{35} \mathrm{~S}$-methionine and two-dimensional gel analyses were carried out as previously described (26).

Reverse transcriptase identification of $5^{\prime}$-end sequence. Avian myeloblastosis virus reverse transcriptase was used to determine the 5 '-end sequence of $\operatorname{clpB}$ mRNA. We used the $c l p B$ antisequence primer, OBG7 (TGGAATTTATTAGT AAGAC; nucleotides 588 to 570), to prime mRNA preparations. We used a basic Klenow sequencing protocol (American Bionetics, Inc., Emeryville, Calif.) but added $\mathrm{KCl}$ (71 $\mathrm{mM}$ ), which is required by the avian myeloblastosis virus reverse transcriptase.
mRNA isolation. We prepared mRNA from MC1009/ pClpB grown in $2 \times$ YT medium (20) at 37 and $42^{\circ} \mathrm{C} \mathrm{(41).} \mathrm{For}$ the $42^{\circ} \mathrm{C}$ preparation, the cells were grown at $30^{\circ} \mathrm{C}$ to an optical density at $436 \mathrm{~nm}$ of $\sim 0.6$, shifted to $42^{\circ} \mathrm{C}$ for $8 \mathrm{~min}$, and then harvested for mRNA preparation.

Growth rate and thermal killing. We grew strains MC1000 and $\mathrm{MC} 1000 \Delta \operatorname{clpB}:: \mathrm{Km}^{\mathrm{r}}$ in M9 minimal medium (20) supplemented with $0.2 \%$ glucose; $20 \mu$ g each of leucine, isoleucine, valine, and methionine per $\mathrm{ml}$; and $10 \mu \mathrm{g}$ of thiamine per $\mathrm{ml}$. We used an overnight $30^{\circ} \mathrm{C}$ culture to inoculate the different temperature conditions. Cell densities at $436 \mathrm{~nm}$ were measured hourly at the indicated temperatures. The parent and mutant strains were grown and handled in parallel at each temperature.

Our thermal killing experiments were modeled after a thermotolerance protocol (37) with several changes: we shifted the cells from 30 to $50^{\circ} \mathrm{C}$ and used several different media. These were YT (20), supplemented M9 (as described above, but lacking methionine), and M9 plus Casamino Acids $(0.5 \%)$, tryptophan $(20 \mu \mathrm{g} / \mathrm{ml})$, thiamine $(10 \mu \mathrm{g} / \mathrm{ml})$, and biotin $(10 \mu \mathrm{g} / \mathrm{ml})$. Samples were taken at timed intervals, diluted, and plated onto YT plates. Survivors were counted following incubation of the plates at $37^{\circ} \mathrm{C}$.

We analyzed the growth and killing data using SigmaPlot (Jandel Scientific, Corte Madera, Calif.). First-order rate constants were calculated by regression from log plots of the growth and survival data.

Nucleotide sequence accession number. The sequence of the $\operatorname{clpB}$ gene has been filed in the GenBank data base under accession number M29364 (designation ECOPROT).

\section{RESULTS}

We have sequenced and studied the $\operatorname{clp} B$ gene of $E$. coli. This gene maps at 56 min on the $E$. coli chromosome and is just upstream of the rRNA $G$ operon (32). In this paper, we have used genetic variants of the $\operatorname{clp} B$ gene to identify the $\mathrm{ClpB}$ protein on two-dimensional gels and to find the conditions under which it is synthesized. This experimental approach also showed that a second, smaller protein, F68.5, was apparently also encoded by the $c l p B$ gene. We mapped the $5^{\prime}$ end of the $\operatorname{clpB}$ mRNA made at 37 and $42^{\circ} \mathrm{C}$ and conducted growth and viability studies, comparing the responses of the wild type and a null mutant strain to hightemperature stress. 
Sequences of the $c l p B$ gene and ClpB protein. The carboxylterminal portion of the $c l p B$ gene sequence was reported by us in 1982 (32). We have now completed the sequence of this gene (see above). We refer the reader to the GenBank entry for detailed examination; all nucleotide sequence numbers used in this paper refer to that entry. We have previously published the amino acid sequence of $\mathrm{ClpB}$ in a survey paper describing the Clp protein family (11).

Location of ClpB on two-dimensional protein gels. We were aided in the identification of the position of $\mathrm{ClpB}$ on the twodimensional $E$. coli protein map by the very generous gift from Peter Reichard of partially purified ClpB isolated from cells grown under anaerobic conditions (band $\alpha$ in reference 9). This sample was tentatively identified as $\mathrm{ClpB}$ by him on the basis of its $\mathrm{N}$-terminal amino acid sequence and size on acrylamide gels (28). We also labeled pClpB plasmid-specific proteins in the maxicell cell strain, CSR603 (29). Throughout this paper we have used the standard alphanumeric designation for the protein spots found on two-dimensional gels (22, $23,25)$. In this system, each spot is identified by a pI group letter (A to $\mathrm{H}$, from acidic to basic) and a number corresponding to the estimated molecular mass (in kilodaltons). Initial two-dimensional gels established that both the purified ClpB sample and the most prominent maxicell protein ran close to spot D84.0 (the protein EF-G) on two-dimensional gels (data not shown). This preliminary location of ClpB near spot D84.0 was in general agreement with the molecular mass $(95.4 \mathrm{kDa})$ and the isoelectric point $(5.28)$ calculated from the ClpB amino acid sequence.

Identification of ClpB as the heat shock protein F84.1. In preliminary $c l p B$-lac $Z$ fusion experiments, we found that $\mathrm{ClpB}$ was expressed at relatively low levels under the normal growth conditions (34). Its identification as a heat shock protein was the result of experiments to determine whether ClpB would be more actively expressed under some less usual growth condition. In one of these experiments, we observed the effect of temperature on the synthesis of ClpB, comparing the proteins synthesized by the $\operatorname{clp} B^{+}, \Delta c l p B:$ : $\mathrm{Km}^{\mathrm{r}}$, and $\mathrm{pClpB}$ strains following heat induction (Fig. 3). F84.1 is one of the 17 prominent heat shock proteins catalogued by Neidhardt and VanBogelen (22) and is slightly larger and more basic than D84.0 (EF-G; marked by $G$ in Fig. 3A and B). Comparison of the wild-type protein patterns before and after the temperature shift revealed that spot F84.1 was present in a low concentration at $30^{\circ} \mathrm{C}$ and that shortly after shifting to $42^{\circ} \mathrm{C}$ it became strongly labeled (circled spots, Fig. 3A and B). When the MC1000 $\Delta$ clpB:: $\mathrm{Km}^{\mathrm{r}}$ protein patterns were compared with those of the wild type, we found that protein $\mathrm{F} 84.1$ was missing both at $30^{\circ} \mathrm{C}$ and after the shift to $42^{\circ} \mathrm{C}$ (circles areas, Fig. 3C and D). Since most other heat shock proteins were produced normally, we concluded that the $\Delta c l p B:: \mathrm{Km}^{\mathrm{r}}$ mutation had a specific effect on the synthesis of F84.1. This conclusion was supported by the protein patterns obtained with the highcopy-number plasmid, pClpB, compared with those obtained with the wild type. The plasmid increased the amount of $\mathrm{F} 84.1$ at $30^{\circ} \mathrm{C}$ and upon thermal induction made a great excess of this protein (circled spot in Fig. 3E and arrow in Fig. 3F). Together, these results conclusively establish that $\operatorname{clp} B$ is the gene for spot F84.1. We will discuss later whether ClpB and F84.1 are identical, given the discrepancy between the calculated and observed sizes.

F68.5 was also influenced by the $c l p B$ gene. In addition to F84.1, Fig. 3 showed a second difference that was influenced by the $c l p B$ gene. F68.5, a smaller (estimated 68.5-kDa) and slightly more basic protein than F84.1, was also missing from the null mutant pattern at both temperatures (compare centers of boxed areas, Fig. $3 \mathrm{~A}$ through D). In the wild type at $30^{\circ} \mathrm{C}, \mathrm{F} 68.5$ was a very minor spot, but its intensity increased substantially after the shift to $42^{\circ} \mathrm{C}$ (boxed spots; Fig. 3A and B). The comparable area from the $42^{\circ} \mathrm{C}$ MC1000 $\Delta$ clpB $:: \mathrm{Km}^{\mathrm{r}}$ protein pattern lacks a spot (compare boxed areas, Fig. 3B and D), suggesting that this protein was also specified by the $\operatorname{clp} B$ gene. Again, the conclusions that F68.5 is a heat shock protein and that it is derived from the clp $B$ gene were substantiated by the $\mathrm{pClpB}$ protein patterns (boxed spots, Fig. 3E and F). This plasmid substantially increased the amount of $\mathrm{F} 68.5$ made at $30^{\circ} \mathrm{C}$ and directed massive synthesis of this protein at $42^{\circ} \mathrm{C}$. The precise relationship of F68.5 to ClpB (F84.1) will be examined in the Discussion.

Transcription start and promoter of $\operatorname{clpB}$. The observation that synthesis of $\operatorname{clpB}$ was increased following a shift to $42^{\circ} \mathrm{C}$ suggested that this gene possessed a heat shock promoter. To determine where transcription of this gene starts, we isolated mRNA from the pClpB plasmid strain and used a specific probe corresponding to the antisequence of nucleotides 566 to 574 to prime reverse transcription back towards the $5^{\prime}$ end of the message. We compared mRNA isolated from cells grown at 37 and $42^{\circ} \mathrm{C}$; the $5^{\prime}$ ends were identical for both temperatures (Fig. 4). Reverse transcripts of the mRNAs showed termination sites at $\mathrm{C}$ and $\mathrm{T}$ nucleotides corresponding to starts at A-525 and G-526 of the GenBank $c l p B$ gene sequence. This result suggested that mRNA was made from the same start positions at both temperatures and that there is probably a single heat shock promoter for the $c l p B$ gene at both normal and high temperatures. Next, we compared the inferred $c l p B$ promoter region with some other characterized heat shock promoter sequences and found a high degree of similarity with the $\sigma^{32}$ consensus -35 and -10 regions (Fig. 5). It may be significant that an 8-nucleotide sequence, TAATTGAG, is present between the -35 and -10 sequences of both the $\operatorname{clp} B$ and $h t r C$ promoters. The $h \operatorname{tr} C$ gene is essential for growth at high temperatures, and it has been suggested that its promoter sequence contributes to preferential expression of that gene at $50^{\circ} \mathrm{C}(27)$.

Growth and survival at high temperature. We have evaluated the $c l p B$ null mutation under two different high-temperature conditions: the maximum temperature permitting growth and sensitivity to killing at $50^{\circ} \mathrm{C}$. We found that the wild-type and null strains grew with identical rates at 30,37 , and $42^{\circ} \mathrm{C}$ (Fig. 6A to $\mathrm{C}$ ). However, during growth at $44^{\circ} \mathrm{C}$, the maximum temperature for both strains, we found that their growth rates differed by a factor of two. The wild type grew with a specific rate constant $(k)$ of $0.167 \mathrm{~h}^{-1}$, while MC1000 $\Delta$ clpB:: $\mathrm{Km}^{\mathrm{r}}$ grew at half that rate $\left(k\right.$ of $\left.0.078 \mathrm{~h}^{-1}\right)$ (Fig. 6D). It should be noted that the slower growth rate of the $c l p B$ null strain at $44^{\circ} \mathrm{C}$ was not apparent for approximately the first $2 \mathrm{~h}$ (about one generation) following inoculation of the $44^{\circ} \mathrm{C}$ culture with a stationary $30^{\circ} \mathrm{C}$-grown culture.

Finally, we have examined the sensitivity of the null mutant to thermal killing following a shift from 30 to $50^{\circ} \mathrm{C}$. We found that the MC1000 $\Delta$ clpB:: $\mathrm{Km}^{\mathrm{r}}$ cells died faster than the wild-type cells $\left(k=-2.09 \mathrm{~h}^{-1}\right.$ versus $k=-1.59 \mathrm{~h}^{-1}$ for the wild type) (Fig. 7). This experiment also showed that the wild-type killing curve possessed a small shoulder, suggesting that the two strains may require a different number of hits to initiate a killing event. 

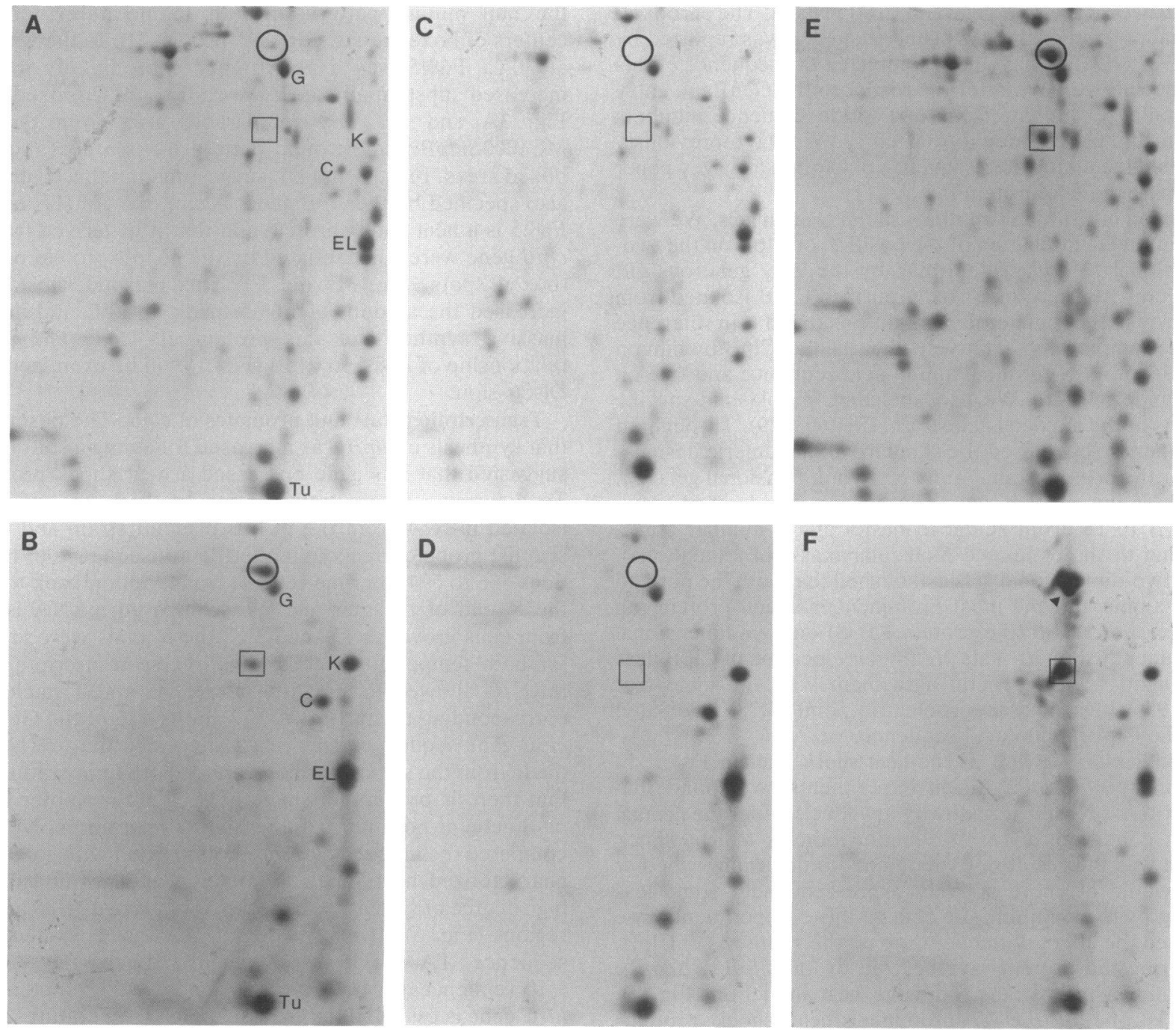

FIG. 3. Two-dimensional gels of E. coli proteins labeled at $30^{\circ} \mathrm{C}$ and after a $42^{\circ} \mathrm{C}$ heat shock. (A and B) $\mathrm{MC} 1000$ (wild type); (C and D) MC1000 $\Delta$ clpB :: $\mathrm{Km}^{\mathrm{r}}$ (null); (E and F) $\mathrm{MC} 1009 / \mathrm{pClpB}$ (plasmid). Proteins shown in panels A, C, and E were labeled at $30^{\circ} \mathrm{C}$. Proteins in panels $\mathrm{B}, \mathrm{D}$, and $\mathrm{F}$ were labeled after the cells had been shifted from 30 to $42^{\circ} \mathrm{C}$ for $8 \mathrm{~min}$. Protein F84.1, or the area in which it should appear, is circled in panels A through E. In panel F, an arrowhead indicates the position of F84.1. Protein F68.5, or the area in which it should appear, is boxed in all gel photographs. In gels from the wild-type strain, several landmark proteins are identified as follows: G, EF-G; K, DnaK; C, protein C62.5 (HtpG); EL, GroEL; Tu, EF-Tu. A 7.5\% acrylamide gel was used in the second dimension. Only part of the total protein pattern is shown.

\section{DISCUSSION}

In this paper we have shown that $\operatorname{clpB}$ specifies the heat shock protein F84.1. We found that the gene possessed a single $\sigma^{32}$-specific promoter which functioned at both 42 and $37^{\circ} \mathrm{C}$. Surprisingly, inactivation of the $c l p B$ gene eliminated not only F84.1 but also the smaller protein that we have designated here F68.5. We have concluded that F68.5 is derived from the same reading frame as $\mathrm{ClpB}$, probably by reinitiation of translation. We found that the $\operatorname{clpB}$ null mutant had a slower growth rate at $44^{\circ} \mathrm{C}$ and died faster at $50^{\circ} \mathrm{C}$ than the wild type $\left(\operatorname{clpB}{ }^{+}\right)$. Some of these observations will be discussed in greater detail below.

Difference between the predicted size for $\mathrm{ClpB}$ and the observed size of F84.1. Our results have established that the clpB gene encodes F84.1, indicating a discrepancy between the size of $\mathrm{ClpB}$ predicted from the nucleotide sequence
(95.4 $\mathrm{kDa})$ and that observed on two-dimensional gels $(84.1$ $\mathrm{kDa}$ ). Such discrepancies for the size of proteins run on SDS gels occur frequently, and the $12 \%$ difference observed in this case is within the expected range. For example, the size discrepancy for HtpG (C62.5) is $12.5 \%$. Alternatively, F84.1 might be derived from $\mathrm{ClpB}$ by processing of $\mathrm{N}$ - or $\mathrm{C}$-terminal amino acids. N-terminal processing has, however, already been ruled out by the work of $P$. Reichard, who has determined the $\mathrm{N}$ terminus of $\mathrm{ClpB}$ purified from anaerobically grown cells (28). Reichard found that the first 20 amino acids of ClpB (band $\alpha$ of reference 9) were identical to the $\mathrm{N}$ terminus predicted from our nucleic acid sequence (28). Although the possibility that F84.1 is derived from ClpB by C-terminal processing cannot be totally ruled out by the information at hand, it is most likely that the apparent ClpB-F84.1 difference simply reflects the error in size deter- 


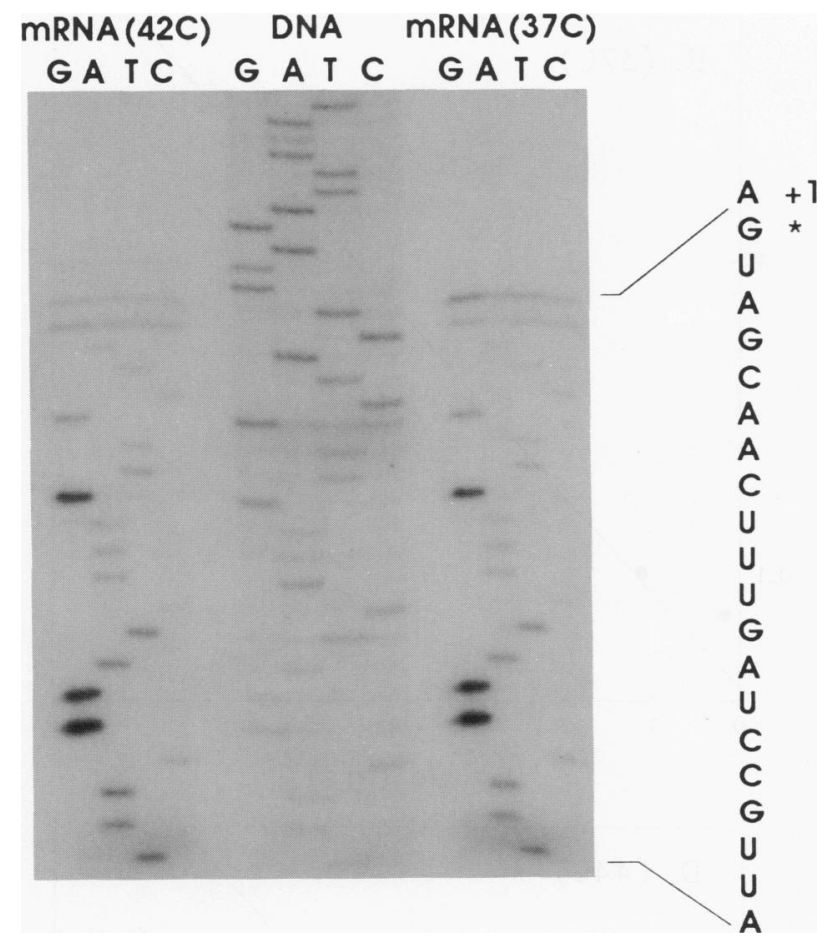

FIG. 4. Primer extension mapping of the $5^{\prime}$ end of $c l p B$ mRNA. An unlabeled primer was used to initiate DNA synthesis from total cellular mRNA isolated from MC1009/pClpB (plasmid) either grown at $30^{\circ} \mathrm{C}$ and shifted to $42^{\circ} \mathrm{C}$ for 8 min before harvesting or grown at $37^{\circ} \mathrm{C}$. The lanes under the heading mRNA show the reverse transcripts terminated with the indicated dideoxynucleotides. The lanes under the heading DNA show the sequences obtained for this region with the same primers on a single-stranded $\operatorname{clpB}$ DNA template. The RNA sequence predicted from these primer extension results is shown on the right. The primary A start is indicated by +1 , and the secondary $\mathrm{G}$ start is noted by an asterisk.

mination by the two-dimensional gel technique. We have tentatively concluded that F84.1 represents the full ClpB sequence.

Relationship of F68.5 to F84.1. Several lines of evidence have led us to conclude that F68.5 is derived from the same reading frame as $\mathrm{F} 84.1(\mathrm{ClpB})$, probably by translational reinitiation. The most compelling evidence for this hypothesis comes from amino acid sequencing data done by $\mathbf{P}$. Reichard (28). During the purification of anaerobic ribonucleotide reductase, Reichard and his colleagues copurified two other proteins (noted as $\alpha$ and $\beta 3$ in reference 9). As stated above, $\alpha$ was identified as ClpB by determining the $\mathrm{N}$-terminal 20 amino acids (28). The sequence and size of $\beta 3$ suggested that it was F68.5. The $\beta$ proteins ran at approximately 60 to $70 \mathrm{kDa}$ on one-dimensional gels (9), and the 9 $\mathrm{N}$-terminal amino acids of $\beta 3$ were MNDQGAEDQ (28). This nearly matches the sequence VNDQGAEDQ predicted from nucleotides 1001 to 1027 of the ECOPROT ClpB sequence (amino acids 148 to 156 ). Codon 148 of $\mathrm{ClpB}$ is GUG, and interestingly, it is preceded by a good ShineDalgarno sequence, GGAGG, separated from this codon by 7 nucleotides. The amino acid sequence data indicate that $\beta 3$ is in the same reading frame as ClpB, the reduced size $(-147$ amino acids) closely matches the observed difference in size between F84.1 and F68.5, and the N-terminal methionine provides compelling evidence for translational reinitiation (8). Both pI and molecular weight values of such an abbreviated ClpB come very close to values estimated for F68.5. A ClpB protein minus $147 \mathrm{~N}$-terminal amino acids would be $16 \mathrm{kDa}$ smaller and would have a pI that is $0.1 \mathrm{pH}$ unit more basic than full-size ClpB. If processing had caused the truncation, $\beta 3$ would have a valine at its $N$ terminus (8). Thus, finding a methionine at the $N$ terminus of $\beta 3$ provides compelling evidence that translational reinitiation caused the production of the smaller protein from the $c l p B$ gene.

Several more circumstantial lines of evidence corroborate the conclusion that F68.5 arises from the $\operatorname{clpB}$ gene. First, the $\operatorname{clp} B$ null mutation was made by replacing an internal segment of the $\operatorname{clp} B$ gene with a $\mathrm{Km}^{\mathrm{r}}$ cassette; no sequence outside of the $\operatorname{clp} B$ gene was changed by this process. Therefore, alteration of this part of the $\operatorname{clp} B$ sequence must be responsible for the loss of F68.5. Examination of reading frames in the vicinity of the deletion-insertion showed only one large enough to accommodate a $68.5-\mathrm{kDa}$ protein, i.e., the $\operatorname{clp} B$ reading frame. Second, $\mathrm{S} 1$ nuclease experiments designed to map mRNAs from the $\operatorname{clp} B$ region showed only one transcript from the sense strand. The extent of the single sense strand transcript was consistent with that predicted for the $\operatorname{clp} B$ gene. No antisense strand transcripts were evident in these experiments $(1,35)$. Third, F68.5 and F84.1 were

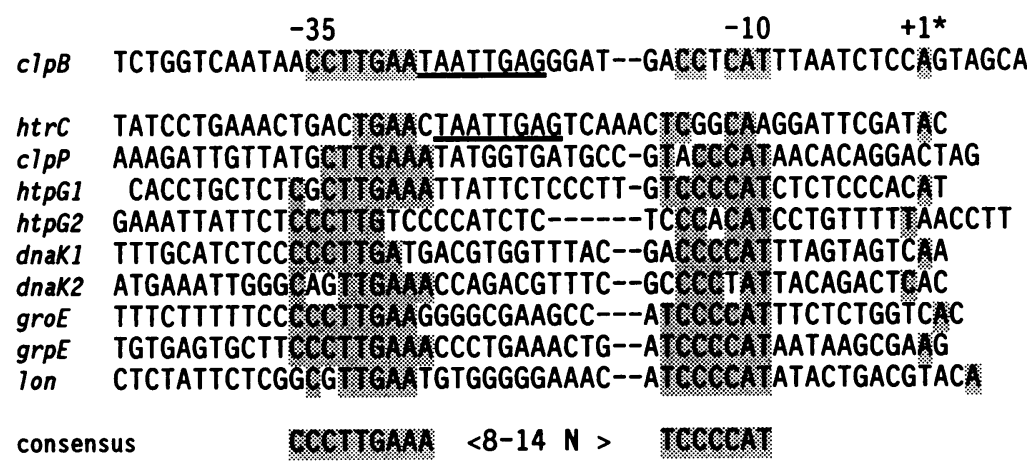

FIG. 5. Comparison of heat shock promoter regions. The nucleotide sequences of the -35 and -10 regions of some $\sigma^{32}$-specific promoters are compared with the region immediately upstream of the $c l p B$ transcription start site. The +1 transcription start site is indicated for $c l p B$ and the other heat shock genes, if it has been determined (shaded). A putative Shine-Dalgarno sequence and the initial ATG codon of $c l p B$ have been underlined. Consensus nucleotides, $>50 \%$ conserved, are shaded. Thick underlining marks a short identical sequence in $c l p B$ and $h$ trC. 

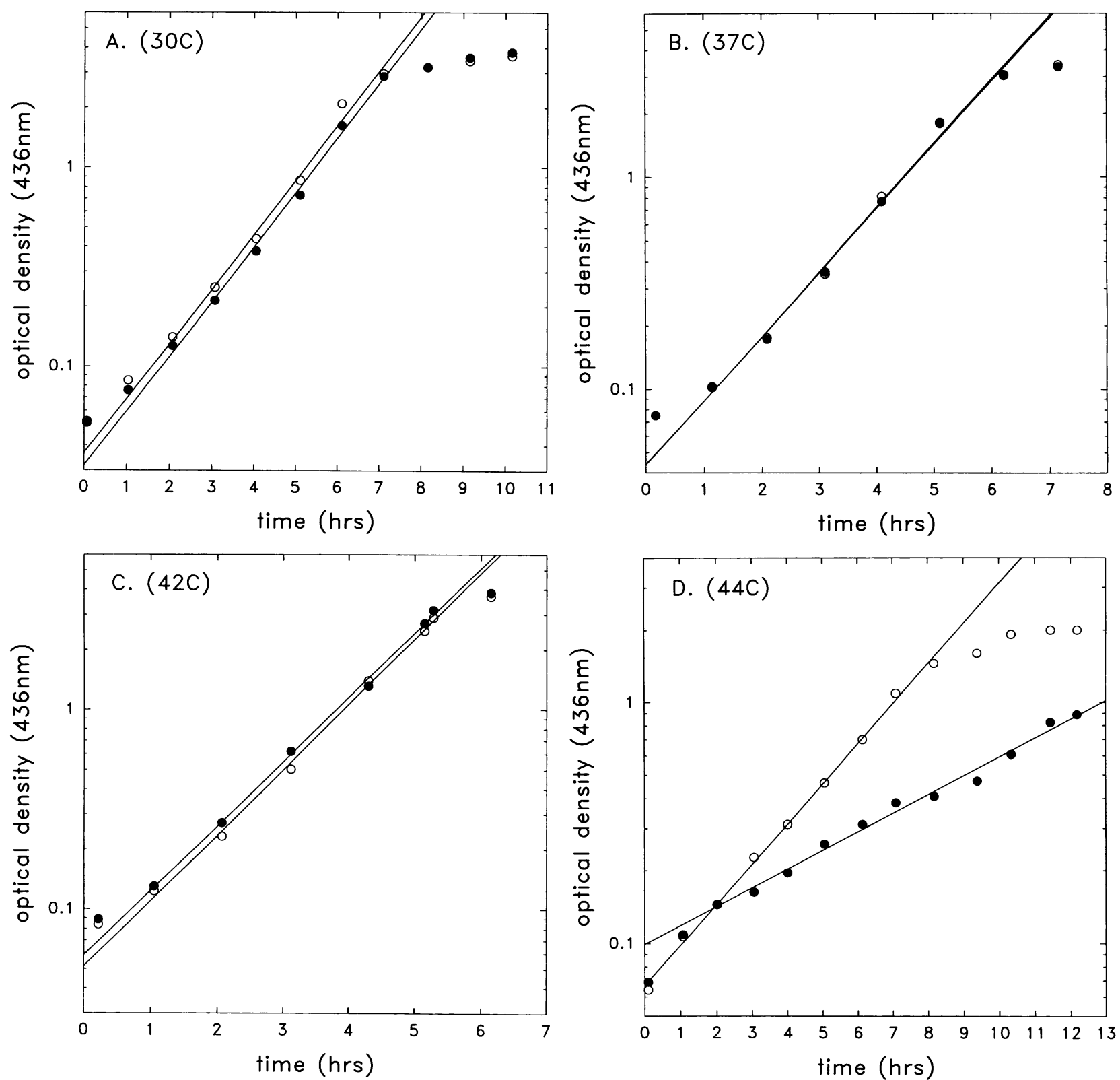

FIG. 6. Growth rates at different temperatures for $\mathrm{MC1000}$ (wild type; $\bigcirc$ ) and $\mathrm{MC} 1000 \Delta c l p B:: \mathrm{Km}^{\mathrm{r}}$ (null; $\bigcirc$ ). Semilogarithmic plots of optical density at $436 \mathrm{~nm}$ versus time in hours are shown for four temperatures of growth in supplemented glucose M9 medium. Growth rate constants determined at each temperature were as follows: panel $\mathrm{A}\left(30^{\circ} \mathrm{C}\right), k=0.274 / \mathrm{h}$ for both strains; panel $\mathrm{B}\left(37^{\circ} \mathrm{C}\right)$, wild-type $k=0.304 / \mathrm{h}$ and null $k=0.302 / \mathrm{h}$; panel $\mathrm{C}\left(42^{\circ} \mathrm{C}\right)$, wild-type $k=0.328 / \mathrm{h}$ and null $k=0.323 / \mathrm{h}$; panel $\mathrm{D}\left(44^{\circ} \mathrm{C}\right)$, wild-type $k=0.167 / \mathrm{h}$ and null $k=0.078 / \mathrm{h}$.

made in coordinate amounts under a variety of conditions, including anaerobiosis (35), heat shock, overproduction by plasmid $\mathrm{pClpB}$, and the combination of $\mathrm{pClpB}$ and heat shock. In each case the ratio of F84.1 to F68.5 was approximately 5:2 (Fig. 3). In particular, the gene dosage result with the plasmid at high temperatures argues against the alternative that $\mathrm{ClpB}$ might be a positive regulator of another gene encoding F68.5 or that ClpB is necessary for the formation of F68.5 through proteolytic processing or stabilization. If this were so, we would expect the ratio of F84.1 and F68.5 to change at very high concentrations of ClpB. Finally, pulsechase experiments showed no product-precursor relationship between F84.1 and F68.5 (35). The data that we and Reichard have accumulated suggest that the smaller protein
(F68.5 or $\beta 3$ ) is derived from the same reading frame as F84.1 by an internal translational initiation mechanism. Mutational analyses of the translational start of F84.1 and F68.5 will allow us to study the interrelationship and action of both proteins.

It is interesting to note similarities between the expression of F84.1 and F68.5 and the MOD5-encoded isozymes in $S$. cerevisiae that are partitioned into the cytoplasm and the mitochondria (10). The MOD5 gene encodes a tRNA-modifying enzyme that functions in both the mitochondria and cytoplasm. Gillman et al. have recently shown that both proteins are encoded by mRNAs having the same 5 ' end, but the mitochondrial isozyme starts at an AUG codon 11 amino acids upstream from the cytosolic isozyme (10). The smaller 


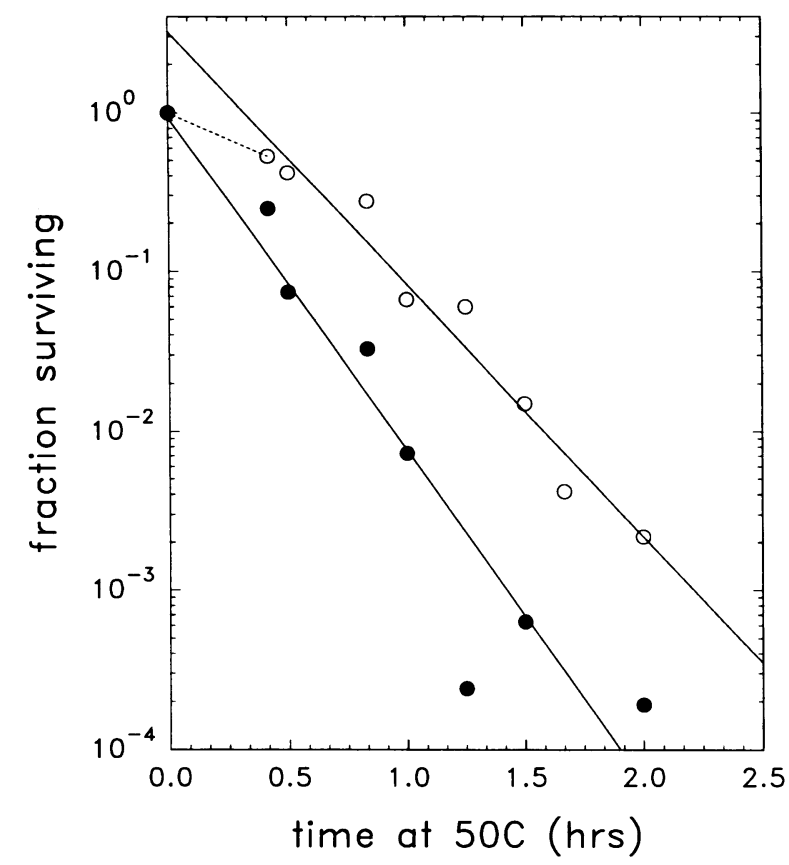

FIG. 7. Death rates at $50^{\circ} \mathrm{C}$ for $\mathrm{MC} 1000$ (wild type, $\bigcirc$ ) and $\mathrm{MC} 1000 \Delta c l p B:: \mathrm{Km}^{\mathrm{r}}$ (null, $\bigcirc$ ); semilogarithmic plot of the fraction of cells surviving versus time held at $50^{\circ} \mathrm{C}$, combined data from two experiments. Cultures of the two strains were grown at $30^{\circ} \mathrm{C}$ then diluted into medium at $50^{\circ} \mathrm{C}$ (see Materials and Methods). Samples were taken at the indicated times, and the numbers of viable cells remaining were determined. Wild-type $k=-1.59 / \mathrm{h}$; null $k=$ $-2.09 / \mathrm{h}$

protein stays in the cytoplasm, while the larger protein is found in both the cytoplasm and mitochondria. Perhaps, in a similar fashion, F84.1 and F68.5 differentially partition to the membrane, periplasm, or cytoplasm. Localization of both proteins in $E$. coli will address this interesting possibility.

F68.5 is a heat shock protein. Although F68.5 was not originally catalogued as a heat shock protein (22), there are several reasons to conclude that this has been an oversight in previous studies rather than a novel observation of this work. First, F68.5 is clearly apparent in several published two-dimensional gels of heat shock proteins but was not marked in these figures $(16,19,23,24)$. Second, in a recent paper, F68.5 was recognized to the extent of being "boxed" in a figure, but this inclusion was presented without comment in the text (39). Finally, the most recently published $E$. coli gene-protein index identifies a new heat shock protein, E72.0 (HtpS) (38), which is undoubtedly the same as F68.5 described in this paper. We have noted that F68.5 had a small but consistently more basic mobility than F84.1 in the first dimension (Fig. 3) and therefore should be included in the $\mathrm{F}$ group. The reason for the previous omission of F68.5 as a heat shock protein may be its relatively minor abundance (compared with the abundance of major heat shock proteins like ClpB, DnaK, and GroEL). It is also possible that strain differences reduce the amount of F68.5 to an even more minor status in some genetic backgrounds. In any event, our results clearly establish that F68.5 is a heat shock protein, and it is now included in the $E$. coli index of heat shock proteins (38).

Influence of ClpB on growth and survival at high temperatures. The finding by Lindquist and coworkers that the $S$. cerevisiae $\mathrm{Hsp} 104$ protein was part of the Clp protein family (18) and the discovery that $\mathrm{ClpB}$ was a heat shock protein led us to investigate the effect the $\Delta c l p B:: \mathrm{Km}^{\mathrm{r}}$ null mutation had on cell growth and survival at high temperatures. In yeast cells, Hsp104 is required for the thermotolerance response of this organism (30). We therefore examined MC1000 and MC1000 $\Delta$ clpB:: $\mathrm{Km}^{\mathrm{r}}$ for their sensitivity to high temperatures. Pretreatment at $42^{\circ} \mathrm{C}$ of cells grown at $30^{\circ} \mathrm{C}$ rendered both strains more resistant to killing at $50^{\circ} \mathrm{C}$ (data not shown). Apparently, in the strain of $E$. coli we used, other $42^{\circ} \mathrm{C}$-induced functions contribute more to induced thermotolerance than $\mathrm{ClpB}$ does. What was clear from these experiments, however, was that the rate of thermal killing at $50^{\circ} \mathrm{C}$ was higher for the null mutant strain than for the parent (Fig. 7). Thus, ClpB had a clear function in protecting cells from the lethal effects of very high temperatures. It is interesting to speculate that because of similarities in the $\sigma^{32}$ promoter sequences of $c l p B$ and $h t r C$, both proteins may be targeted for synthesis at extreme temperatures (27).

Growth measurements of MC1000 and MC1000 $\mathrm{MclpB}$ :: $\mathrm{Km}^{\mathrm{r}}$ at different temperatures showed that the slow-growth phenotype for the $\operatorname{clpB}$ null mutant appeared at a sharp temperature demarcation between 42 and $44^{\circ} \mathrm{C}$. Interestingly, even this phenotype did not appear for several hours after transfer to $44^{\circ} \mathrm{C}$. Examination of the proteins made by parent and null strains after prolonged exposure to 44 or $50^{\circ} \mathrm{C}$ will allow us to determine whether the synthesis or persistence of other proteins is influenced by $\mathrm{ClpB}$ and perhaps lead to an understanding of the role of ClpB at high temperatures.

Concluding remarks. Employing $\operatorname{clp} B$ wild-type, deletion, and plasmid overproduction strains, we have used twodimensional gels, reverse transcription of mRNA, and hightemperature growth and survival kinetics to study the synthesis and influence of ClpB in the cell. We have drawn the following conclusions from the results presented in this paper. (i) $\mathrm{ClpB}$ is the heat shock protein F84.1. (ii) The $c l p B$ gene is synthesized from a $\sigma^{32}$-specific promoter. (iii) $E$. coli protein F68.5 is also a heat shock protein and is derived from the $c l p B$ reading frame. (iv) The ClpB protein is necessary for optimal growth and survival at high temperatures.

\section{ACKNOWLEDGMENTS}

We appreciate the generous consideration of Takashi Yura for withholding publication of his work until we could complete our manuscript. We also extend special thanks to Peter Reichard for his gift of ClpB protein and for sharing his unpublished results of the $\mathrm{N}$ terminal amino acid sequence of purified $\mathrm{ClpB}(\alpha)$ and $\beta 3$ proteins. We are grateful to Susan Lindquist for sharing unpublished information with us on the yeast Hsp104 protein and her studies with $c l p B$ mRNA. We thank Marit Warrer for excellent and untiring assistance with the two-dimensional gels, Ciaran Condon and Richard Miller for their helpful comments on the manuscript, Alex Tzagoloff for pointing out the $S$. cerevisiae MOD5 reference, Malcolm Winkler for giving us pMB2109 and JC7623 and for helpful suggestions concerning the gene replacement experiments, Karen Berg for the pKB3-5 construction, and Serap Aksoy for making M13 BP1.

This work was supported by grants from the Danish Center of Microbiology to S.P. and NIH grant GM24751 to C.L.S.

\section{ADDENDUM}

After completion of this study, we learned that T. Yura and coworkers and S. Lindquist (18) and coworkers had independently found that $\operatorname{clp} B$ is a heat shock gene. The report of Yura and coworkers (15) precedes this paper in this issue. 


\section{REFERENCES}

1. Aksoy, S. 1982. Ph.D. thesis. Columbia University, New York, N.Y.

2. Arps, P. J., and M. E. Winkler. 1987. Structural analysis of the Escherichia coli K-12 hisT operon by using a kanamycin resistance cassette. J. Bacteriol. 169:1061-1070.

3. Berg, K. 1988. Ph.D. thesis. Columbia University, New York, N.Y.

4. Brosius, J. 1984. Plasmid vectors for the selection of promoters. Gene 27:151-160.

5. Casadaban, M., and S. Cohen. 1980. Analysis of gene control signals by DNA fusion and cloning in Escherichia coli. J. Mol. Biol. 138:179-207.

6. Chin, D. T., S. A. Goff, T. Webster, T. Smith, and A. L. Goldberg. 1988. Sequence of the lon gene in Escherichia coli. A heat-shock gene which encodes the ATP-dependent protease La. J. Biol. Chem. 263:11718-11728.

7. Clarke, L., and J. Carbon. 1976. A colony bank containing synthetic ColE1 hybrid plasmids representative of the entire $E$. coli genome. Cell 9:91-99.

8. Cone, K. C., and D. A. Steege. 1985. Messenger RNA conformation and ribosome selection of translational reinitiation sites in the lac repressor mRNA. J. Mol. Biol. 186:725-732.

9. Eliason, R., M. Fontecave, H. Jörnvall, M. Krook, and P. Reichard. 1990. The anaerobic ribonucleoside triphosphate reductase from Escherichia coli requires S-adenosylmethionine as a cofactor. Proc. Natl. Acad. Sci. USA 87:3314-3318.

10. Gillman, E. C., L. B. Slusher, N. C. Martin, and A. K. Hopper. 1991. MOD5 translation initiation sites determine $N^{6}$-isopentyladenosine modification of mitochondrial and cytoplasmic tRNA. Mol. Cell. Biol. 11:2382-2390.

11. Gottesman, S., C. Squires, E. Pichersky, M. Carrington, M. Hobbs, J. S. Mattick, B. Dalrymple, H. Kuramitsu, T. Shiroza, T. Foster, W. P. Clark, B. Ross, C. L. Squires, and M. R. Maurizi. 1990. Conservation of the regulatory subunit for the Clp ATP-dependent protease in prokaryotes and eukaryotes. Proc. Natl. Acad. Sci. USA 87:3513-3517.

12. Gross, C. A., D. B. Straus, J. W. Erickson, and T. Yura. 1990. The function and regulation of heat shock proteins in Escherichia coli, p. 167-189. In R. I. Morimoto, A. Tissieres, and C. Georgeopoulos (ed.), Stress proteins in biology and medicine. Cold Spring Harbor Laboratory, Cold Spring Harbor, N.Y.

13. Hwang, B. J., W. J. Park, C. H. Chung, and A. L. Goldberg. 1987. Escherichia coli contains a soluble ATP-dependent protease (Ti) distinct from protease La. Proc. Natl. Acad. Sci. USA 84:5550-5554.

14. Katayama-Fujimura, Y., S. Gottesman, and M. R. Maurizi. 1987. A multiple-component, ATP-dependent protease from Escherichia coli. J. Biol. Chem. 262:4477-4485.

15. Kitagawa, M., C. Wada, S. Yoshioka, and T. Yura. 1991. Expression of ClpB, an analog of the ATP-dependent protease regulatory subunit in Escherichia coli, is controlled by a heat shock $\sigma$ factor $\left(\sigma^{32}\right)$. J. Bacteriol. 173:4247-4253.

16. Kroh, H. E., and L. D. Simon. 1990. The ClpP component of Clp protease is the $\sigma^{32}$-dependent heat shock protein F21.5. J. Bacteriol. 172:6026-6034.

17. Lindquist, S. 1986. The heat shock response. Annu. Rev. Biochem. 55:1151-1191.

18. Lindquist, S. (University of Chicago). 1991. Personal communication.

19. Matthews, R. G., and F. C. Neidhardt. 1989. Elevated serine catabolism is associated with the heat shock response in Escherichia coli. J. Bacteriol. 171:2619-2625.

20. Miller, J. H. 1972. Experiments in molecular genetics. Cold Spring Harbor Laboratory, Cold Spring Harbor, N.Y.

21. Nath, I., and S. Laal. 1990. Nucleotide sequence and deduced amino acid sequence of Mycobacterium leprae gene showing homology to bacterial atp operon. Nucleic Acids Res. 18:4935.

22. Neidhardt, F. C., and R. A. VanBogelen. 1987. Heat shock response, p. 1334-1345. In F. C. Neidhardt, J. L. Ingraham, K. B. Low, B. Magasanik, M. Schaecter, and H. E. Umbarger (ed.), Escherichia coli and Salmonella typhimurium: cellular and molecular biology. American Society for Microbiology, Washington, D.C.

23. Neidhardt, F. C., R. A. VanBogelen, and E. T. Lau. 1983. Molecular cloning and expression of a gene that controls the high-temperature regulon of Escherichia coli. J. Bacteriol. 153: 597-603.

24. Paek, K.-H., and G. C. Walker. 1986. Defect in expression of heat-shock proteins at high temperature in $x \operatorname{th} A$ mutants. $\mathrm{J}$. Bacteriol. 165:763-770.

25. Pedersen, S., S. Reeh, J. D. Friesen, P. L. Bloch, and F. C. Neidhardt. 1978. A nomenclature for $E$. coli proteins. Cell 14:186-190.

26. Pedersen, S., S. Reeh, J. Parker, R. J. Watson, J. D. Friesen, and N. P. Fiil. 1976. Analysis of proteins synthesized in ultraviolet light-irradiated Escherichia coli following infection with bacteriophage $\lambda \mathrm{d} r \mathrm{f}^{d} 18$ and $\lambda \mathrm{d} f u s-3$. Mol. Gen. Genet. 196:135-140.

27. Raina, S., and C. Georgeopoulos. 1990. A new Escherichia coli heat shock gene, $h t r C$, whose product is essential for viability only at high temperatures. J. Bacteriol. 172:3417-3426.

28. Reichard, P. (Karolinska Institute). 1991. Personal communication.

29. Sancar, A., A. M. Hack, and W. D. Rupp. 1979. Simple method for identification of plasmid-coded proteins. J. Bacteriol. 137: 692-693.

30. Sanchez, Y., and S. L. Lindquist. 1990. HSP104 required for thermotolerance. Science 248:1112-1115.

31. Schlesinger, M. J. 1990. Heat shock proteins. J. Biol. Chem. 265:12111-12114.

32. Shen, W.-F., C. Squires, and C. L. Squires. 1982. Nucleotide sequence of the $r r n G$ ribosomal RNA promoter region of Escherichia coli. Nucleic Acids Res. 10:3303-3313.

33. Shiroza, T., and H. Kuramitsu. 1988. Sequence analysis of the Streptococcus mutans fructosyltransferase gene and flanking regions. J. Bacteriol. 170:810-816.

34. Squires, C. L., and J. Fu. Unpublished data.

35. Squires, C. L., S. Pedersen, B. M. Ross, and C. Squires. Unpublished data.

36. Tybulewicz, V. L. J., G. Falk, and J. E. Walker. 1984. Rhodopseudomonas blastica atp operon. Nucleotide sequence and transcription. J. Mol. Biol. 179:185-214.

37. VanBogelen, R. A., M. A. Acton, and F. C. Neidhardt. 1987. Induction of the heat shock regulon does not produce thermotolerance in Escherichia coli. Genes Dev. 1:525-531.

38. VanBogelen, R. A., M. E. Hutton, and F. C. Neidhardt. 1990. Gene-protein database of Escherichia coli K-12: edition 3. Electrophoresis 11:1131-1166.

39. VanBogelen, R. A., and F. C. Neidhardt. 1990. Ribosomes as sensors of heat and cold shock in Escherichia coli. Proc. Natl. Acad. Sci. USA 87:5589-5593.

40. Walker, J. E., M. Saraste, M. J. Runswick, and N. J. Gay. 1982. Distantly related sequences in the $\alpha$ - and $\beta$-subunits of ATP synthase, myosin, kinases and other ATP-requiring enzymes and a common nucleotide binding fold. EMBO J. 1:945-951.

41. Wong, S. C., and A. T. Abdelal. 1990. Unorthodox expression of an enzyme: evidence for an untranslated region within carA from Pseudomonas aeruginosa. J. Bacteriol. 172:630-642.

42. Zagursky, R. J., K. Baumeister, N. Lomax, and M. L. Berman. 1985. Rapid and easy sequencing of large linear double-stranded DNA and supercoiled plasmid DNA. Gene Anal. Tech. 2:89-94. 